\title{
Liminal Legality: Salvadoran and Guatemalan Immigrants' Lives in the United States $^{1}$
}

\author{
Cecilia Menjívar \\ Arizona State University
}

\begin{abstract}
This article examines the effects of an uncertain legal status on the lives of immigrants, situating their experiences within frameworks of citizenship/belonging and segmented assimilation, and using Victor Turner's concept of liminality and Susan Coutin's "legal nonexistence." It questions black - and - white conceptualizations of documented and undocumented immigration by exposing the gray area of "liminal legality" and examines how this in-between status affects the individual's social networks and family, the place of the church in immigrants' lives, and the broader domain of artistic expression. Empirically, it draws on ethnographic fieldwork conducted among Salvadoran and Guatemalan immigrants in San Francisco, Los Angeles, Washington, D.C., and Phoenix from 1989 to 2001. The article lends support to arguments about the continued centrality of the nation-state in the lives of immigrants.
\end{abstract}

\section{INTRODUCTION}

This article examines the effects of legal status on the lives of contemporary immigrants; that is, the immigrants' relationship to the body of law that governs their lives as it impinges on many vital spheres of their

\footnotetext{
${ }^{1}$ I prepared this article while I was a visiting scholar at the Maison des Sciences de l'Homme, Paris, in spring 2003 and would like to acknowledge the institutional support. I presented it in the thematic session Culture, Migration and Diaspora at the American Sociological Association meetings in Atlanta, August 2003, organized by Min Zhou. I also presented versions at the Center for Migration and Development Colloquium Series, Princeton University, and at California State University, Northridge. I thank all these audiences for their very helpful comments. I am also grateful to Victor Agadjanian and the $A J S$ reviewers for excellent suggestions, to Belinda Herrera and Cecilia Martinez Vasquez for first-rate research assistance, and to Mary Fran Draisker for preparing this manuscript for submission. All remaining weaknesses are, of course, mine alone. Direct correspondence to Cecilia Menjívar, Department of Sociology, Arizona State University, Tempe, Arizona, 85287-4802. E-mail: menjivar@asu.edu
}

(C) 2006 by The University of Chicago. All rights reserved.

0002-9602/2006/11104-0002\$10.00

AJS Volume 111 Number 4 (January 2006): 999-1037 
American Journal of Sociology

existence. Empirically I rely on the experiences of Salvadoran and Guatemalan immigrants in four U.S. cities. Immigrants' legal status shapes who they are, how they relate to others, their participation in local communities, and their continued relationship with their homelands. An undocumented status can affect anything from the immigrants' health risks (Guttmacher 1984), their vulnerability in the streets (Hirsch 2003), and their ability to combat domestic violence (Salcido and Adelman 2004), to their health-seeking behavior (Menjívar 2002b), their chances in the labor market (Simon and DeLey 1984; Uriarte et al. 2003), their wages (Massey, Durand, and Malone 2002), and their identities (Rodriguez and Hagan 2004). Indeed, legal statuses create a class of immigrants with rights and privileges distinct from those holding temporary work visas (Freeman 2004), and it can be said that documented and undocumented immigrants have such different experiences that they can be regarded as two different social classes (Durand cited in Hirsch 2003).

Examinations of the effects of legal status on different spheres of life have concentrated on the differences between documented and undocumented status. I focus on the gray area between these legal categories, how this "in-between" status or liminal legality shapes different spheres of life-the immigrant's immediate sphere of social networks and family, the community-level place of religious institutions in the immigrants' lives, and the broader domain of artistic expression. Furthermore, with few exceptions (see Rodriguez and Hagan 2004), the effect of legal status on these areas has not received much attention in research. My examination illustrates how the impact of legal status extends far beyond labor force participation and access to services-areas that have been researchedto encompass sociocultural spheres as well.

The case of Salvadorans and Guatemalans presents an opportunity to capture these effects. For reasons having to do with the context they exited, in which the United States played a key role in political conflicts in the sending countries, these Central Americans in the United States have been categorized neither as strictly economic migrants nor as political refugees. Occasionally they are granted temporary relief from deportation with multiple and confusing deadlines for applications and renewals of permits and convoluted application procedures (e.g., fees, forms, photos, fingerprints, proofs of residence, and innumerable caveats and conditions). Indeed, so much work is involved in preparing these applications and information is so difficult to obtain that a veritable industry has developed among document preparers, notaries, and other entrepreneurs (some of whom are not particularly well qualified) to fulfill the needs of Central Americans applying for the different dispensations (see Coutin 2000; Mahler 1995). This situation creates enormous anxiety, as each deadline accentuates these immigrants' precarious situation, which for many has gone 
on for over two decades. This aspect of life among these immigrants has been noted in other studies and has been referred to as "permanent temporariness" (Bailey et al. 2002).

It also has been life threatening or simply unfeasible economically for these immigrants to return to countries either at war or suffering the devastation of years of war. Central Americans have been squeezed between an extremely harsh and even dangerous context of exit and an exceptionally inhospitable context of reception. This highly ambiguous character of Central American migration stems in no small part from these immigrants' complex position vis-à-vis U.S. immigration law, which in turn has been a product of Cold War politics and the U.S. role in the civil wars in Guatemala and El Salvador.

It is not simply an undocumented status that matters theoretically and analytically, but the long-term uncertainty inherent in these immigrants' legal status. This uncertain status-not fully documented or undocumented but often straddling both-has gone on for years and permeates many aspects of the immigrants' lives and delimits their range of action in different spheres, from job market opportunities and housing, to family and kinship, from the place of the church in their lives and their various transnational activities, to artistic expressions. Arguably exceptional, the legal ambiguity of Guatemalans and Salvadorans may be deemed irrelevant to broader conceptualizations of immigrant life. However, it is precisely the uncertainty of these immigrants' legality that presents an opportunity to better capture how political decisions embodied in immigration law constrain and enable human action. Examining this ambiguity as directly linked to state power in a time when the nationstate is believed by some to be in decline highlights the central role the state still plays in shaping and regulating immigrants' lives.

This examination also permits reflection on the organization of membership in an increasingly mobile and transnationally structured world and the challenges that immigration may pose to the theory and practice of citizenship. The case of Salvadorans and Guatemalans is not an exception in today's world, as their experiences parallel those of other immigrant groups in the United States and in other major receiving countries. $^{2}$ In her research on immigration to Spain, Calavita (1998, p. 530) observes that immigration law "actively 'irregularizes' people by making it all but impossible to retain legal status over time. Indeed, it makes little sense to draw distinctions between legal and illegal immigrants . . . because the law ensures that legal status is temporary and subject to con-

\footnotetext{
${ }^{2}$ There are many other cases. Take, e.g., Somali detainees in the United States, for whom legal uncertainty includes debates about whether they can be deported to a country that might not have a government (Dow 2004, p. 281).
} 
American Journal of Sociology

tinuous disruptions." Thus, in major receiving countries contemporary immigration law creates and recreates an excluded population and ensures its vulnerability and precariousness by blurring the boundaries of legality and illegality to create gray areas of incertitude, with the potential to affect broader issues of citizenship and belonging.

There are important sociodemographic and cultural differences between Salvadorans and Guatemalans, in particular their ethnic composition. For example, many Guatemalans in the United States are Maya and may not speak Spanish, and there are differences among the various Maya groups as well, which make intraethnic relations much more relevant for Guatemalans than for Salvadorans. Notwithstanding these differences, Guatemalan and Salvadoran immigrants' experiences of immigration and of their context of exit and reception have been very similar. Furthermore, both groups include well-educated as well as unskilled immigrants, political refugees, wealthy landowners, and peasants (Rodriguez and Hagan 1999). In spite of the sociodemographic and cultural differences between Salvadorans and Guatemalans, for analytical purposes I will consider them as a single group due to their similarities on those key aspects that I develop in this article, noting contrasts between the two when appropriate.

\section{CAPTURING LIMINAL LEGALITY ANALYTICALLY}

The importance of the broader context of reception for immigrants' lives is well known (Portes and Zhou 1993; Portes and Rumbaut, 1996; Reitz 1998; Menjívar 2000). Portes and Rumbaut (1996) note that the context of reception channels immigrants in different directions, often altering the link between individual skills and expected rewards. Similarly, segmented assimilation (Portes and Zhou 1993) calls attention to the multiple outcomes of immigrant incorporation, as not all immigrants have the same resources or face the same conditions in destination areas, a situation that leads to disparate outcomes. In these conceptualizations, the context of reception includes extrapersonal factors such as immigration laws and the labor market that together shape opportunity structures. Immigration policy determines who stands inside or outside the law (or in between) and whether immigrants qualify as full participants in society, as it dictates whether they will have access to resources and, if they do, to what kind (Menjívar 2000) and for how long. Thus, the political-economic context in which immigrants arrive translates into either a favorable receptionwith relaxed or even friendly immigration laws and a viable economy with abundant jobs - or an adverse one, with stiff immigration laws and fewer jobs, as in the case of the Salvadoran and Guatemalan immigrants. 
My focus on only the political (legal) aspect of the context of reception does not imply monocausality, for a single factor alone cannot possibly lead to any of the multiple outcomes I examine here. I have singled it out because in all the sites I conducted fieldwork, regardless of the specific aim of the study, legal status emerged as paramount in the immigrants' lives. It highlights the enduring power of the nation-state in creating immigration laws that shape immigrant integration, playing a significant role in opportunities for work, rights, and social benefits (Aleinikoff 2001, p. 267). ${ }^{3}$ As Freeman (2004, p. 950) notes, "Immigration laws, observed or violated, necessarily precede and often constrain the migrants' interaction with markets, welfare, and cultural regulations." Thus, an examination of the lives of individuals who are ambiguously situated legally can lead to fruitful theorizing about incorporation, assimilation, citizenship, belonging, and exclusion.

The legal instability at the heart of this discussion is closely linked to broader questions of citizenship and the state, as the concept of citizenship is used to describe a number of discrete but related phenomena surrounding the relationship between the individual and the polity (Rubenstein and Adler 2000). Citizenship as legal status-whom the state recognizes as a citizen and the formal basis for the rights and responsibilities of the individual in the state-shapes the immigrants' membership in society and their understandings of their place in it. Lengthy uncertain legal statuses determine if, how, and when immigrants will become fully legal and then citizens (through naturalization). Thus, spaces between conventional legal categories affect the immigrants' immediate lives as well as long-term membership, thus raising the possibility of new forms of citizenship through migration. ${ }^{4}$ Legal citizenship in the United States is no longer easy to attain, and even permanent residence has proven an elusive dream for many. Furthermore, as De Genova (2002) notes, the different legal statuses-documented, undocumented-would be inconceivable were it not for the value they produce to society, and, as such, they are fundamentally inseparable from citizenship. The multiple legal categories in immigration law, including in-between statuses, thus shape immigrant long-term incorporation, and thus, broader forms of citizenship and community belonging (and exclusion).

In debates about the link between citizenship and immigration some scholars stress the legal dimension of citizenship, while others examine

\footnotetext{
${ }^{3}$ By "the nation-state" I refer to the wealthy states of the major receiving countries. ${ }^{4}$ Theorists of citizenship have proposed new categories to capture the experiences of today's immigrants. Hammar (1990, p. 13), e.g., suggests the category of "denizens" to refer to immigrants who have lived a long time in the host country and have developed such strong ties that they in fact may constitute a new category of citizens.
} 
American Journal of Sociology

the set of rights an individual has by virtue of belonging to a national community, and still others study the participatory dimensions of the concept (Martiniello 1997). Bosniak (2000) differentiates four "strands" or dimensions of citizenship: rights, legal status, political activity, and collective activity and sentiment. Coutin (2000a) notes that individuals can move between the different forms of citizenship and can use one dimension to gain another. And movements between membership and exclusion, one dimension of citizenship and another, the national and the nonnational, legitimacy and illegitimacy may be as important as redefinitions of the concept of citizenship itself (Coutin 2000a, p. 586).

Bosniak (2000) notes that legal citizenship has enormous legitimizing functions; to characterize social practices in the language of citizenship recognizes them as politically and socially consequential. Even when immigrants perform tasks through which they participate in and contribute to society (e.g., raising children, working, and paying taxes), they are excluded from full membership if they lack full (permanent) legal recognition. And the assumption in discussions of citizenship that temporary workers and undocumented immigrants eventually gain access to permanent residence (as over time there seemed to be a convergence toward full incorporation [Zolberg 2000, pp. 514-15] $)^{5}$ is more uncertain and complex today. References to undocumented immigration are occasionally made in debates about citizenship, but these tend to be marginal and without a deep exploration of the conceptual link binding the exclusion of illegal immigrants (Rubio-Marín 2000, p. 6). The exclusion of undocumented immigrants from these discussions shows "how deeply entrenched are the assumptions about national and territorial sovereignty" (Rubio-Marín 2000, p. 238). In this regard liminal legal spaces, the gray areas between documented and undocumented, remain even less theorized or explored, although their examination can lead to a rethinking of legal citizenship as well as broader forms of citizenship and of the place of the nation-state in an increasingly mobile and transnational world.

Indeed, an examination of in-between legal statuses brings to the fore the continued power of the nation-state. In spite of arguments about its decline, citizenship as legal status remains a largely national enterprise (Bosniak 2000, 1998) because the very designations "legal," "undocumented," "regular," and "irregular" (and, I would add, in-between categories) are intelligible only by reference to both the rule of state territorial sovereignty and its limitations (Bosniak 1991, p. 742). Some scholars emphasize the decline or obsolescence of the nation-state and the devaluation

\footnotetext{
${ }^{5}$ Bauböck (1994), e.g., suggests that since immigrants become members by participating in civil society, in daily life, housing, and labor markets, they should be seen as full members of society after a minimum period of residence.
} 
of nation-based citizenship resulting from the extension of certain rights to noncitizens, which signals the emergence of postnational citizenship (see Soysal 1994; Jacobson 1996). From this viewpoint the nation-state model has given way to a new regime in which citizenship and human rights have become increasingly legitimated at the transnational level (Soysal 2000). ${ }^{6}$ Others argue that the state is only being transformed through the growth of interconnections among states and individuals around the world, by deregulation and privatization and, thus, particular aspects of the institution of citizenship will be transformed but not erased (Sassen 2000, 2002). As Bloemraad (2004, p. 421) observes, while sovereignty might be differentiating, new forms of citizenship act to build the nation-state rather than destroy it. ${ }^{7}$

The case I examine here lends support to the scholarship that emphasizes the enduring power of the nation-state, particularly with regard to citizenship-and in doing so, it also upholds central tenets of the segmented assimilation framework (see Portes and Zhou 1993). Although transformations in the nation-state as a result of movements of capital and globalization may translate into changes in citizenship, these might not necessarily lead to openness. There may be more flexibility, but also more tightening and restrictions, as well as the creation of new barriers, legal categories, and obstacles, particularly when migratory movements are linked to terrorism in the global arena. Thus, increased interconnections among states and individuals can lead to reduced access to permanent legality and the tightening of immigration laws when national security is paramount. The proliferation of such interconnections has involved "the emergence of a sociohistorically particular configuration of migrant illegality" (De Genova 2002, p. 424). Indeed, there has been an effort to reinvigorate, or revalorize, the legal status of citizenship-either by making it count for more or by making it more difficult to obtain

\footnotetext{
${ }^{6}$ This view has been criticized from different angles. Bosniak (2000, p. 452) notes that this might be the case in Europe, where citizenship presents a departure from the national model, but even there this is limited both in kind and effect. Also, the claim for postnational citizenship risks overstating the degree to which supranational human rights regimes may actually protect individuals. Martiniello (1997) observes that only when nonnationals enjoy full political rights in Europe will we be able to talk about a postnational citizenship. And Sassen (2003), who situates the institution of citizenship in a broad historical framework, points out that this institution has gone through many transformations in history because it is embedded in the specifics of each era, and what we see now is part of this history.

${ }^{7}$ Some scholars point to increases in dual citizenship rates as evidence of the emergence of postnational citizenship. However, Bloemraad (2004) finds little empirical support for a strict model of postnational citizenship. She rightly notes that dual citizenship itself reinforces the relevance of nation-states because they continue to be the grantors of citizenship.
} 
American Journal of Sociology

(Bosniak 1998, p. 30). Coutin (2000a, p. 589) finds that increasingly restrictive immigration policies have sharpened distinctions between U.S. citizens and permanent legal residents and have thereby made citizenship (through naturalization) more important. And as Aleinikoff (2001, p. 267) observes, the state's physical boundaries (the border) and its political and legal boundaries (membership) are closely related: "Whom states chose to admit as immigrants in part determines who shall be citizens." In this context, lengthy periods of legal instability deeply affect the immediate lives of immigrants in multiple ways, as well as their long-term prospects for seeking and attaining full citizenship, which in turn shapes other forms of belonging and membership. For instance, Jones-Correa (1998) observes that the length of time it takes for Latinos to become citizens has great implications for their community.

In an era when publics in immigrant-receiving countries feel besieged and threatened by images linking immigrants with terrorists and drug smugglers (Kil and Menjívar, in press), states will be less inclined to extend rights and protection to foreigners. The continued militarization of the southern U.S. border attests to increasing efforts to fortify, not dilute, physical (and legal) borders and, thus, to the power and centrality of the nation-state. As Guiraudon and Joppke (2001, p. 15) note, those who proclaim the death of the state overlook the fact that governments give up some of their authority only to increase their capacity to control movement. Thus, global economic and political trends might have transformatory effects on national states, but not necessarily in the same direction, creating a kind of "social schizophrenia," to use Castells's (1989, p. 347) term. In this situation the economies become more integrated and open, but the political spheres do the opposite, with direct implications for citizenship, belonging, and exclusion.

Furthermore, as segmented assimilation theory would suggest (Portes and Zhou 1993), legal categories create a stratified system of belonging, as not all groups are treated equally before immigration law. Legal categories mark immigrants not only as nonnationals but also as deportable, and these categories become marks of exclusion. Not all groups have equal access to permanent statuses, an aspect of immigration law that undermines the assumption of equality of status and belonging in citizenship. Thus, in line with segmented assimilation theorizing (Portes and Zhou 1993), assimilation in receiving societies does not occur monolithically, and the multiple categories created by the law generate layered or fragmented forms of belonging. Moreover, my examination may contribute to debates about the relevance of classic assimilation theory frameworks for contemporary immigrants (see Alba and Nee 2003), as legal status has clearly become an important axis of stratification that can shape immi- 
grants' assimilation in critical ways, but has not received enough theoretical or analytical attention in these discussions.

As a conceptual guide to capture the Central American immigrants' uncertain legality, I borrow from the work of two anthropologists. First, Victor Turner's classic concept of liminality, used to capture the ambiguous periods of rites de passage and conceptualized as a transitional intervening period between "two relatively fixed or stable conditions" (Turner 1967, p. 93) including legal status, is appropriate here. ${ }^{8}$ In Turner's view, "the transitional-being or 'liminal persona' is defined by a name and by a set of symbols. The structural invisibility of the liminal personae has a twofold character. They are at once no longer classified and not yet classified" (Turner 1967, pp. 95-96).

In a direction that Turner's analysis already suggests, the immigrants' uncertain legality transforms them into "transitional beings," who are "neither one thing or another; or maybe both; or neither here nor there; or maybe nowhere . . . and are at the very least 'betwixt and between' all the recognized fixed points in space-time of structural classification" ( Turner 1967, p. 96). It is the "betwixt-and-between" period and the process of the midtransition exposed by Turner's analysis that, in my view, captures the uncertain legality I examine here. Although in Turner's view these transitory stages are empowering and are positive moments in social transformation, when they are extended indefinitely (as in the case of the immigrants in this discussion) they can breed uncertainty and lose their empowering potential. Thus, an examination of an extended marginal legality can lay bare crucial aspects of immigrant life essential for theorizing about immigrant incorporation, exclusion, citizenship, and belonging that lie at the core of varied forms of assimilation.

I also borrow from the work of Susan Coutin (2000b). In her study of the complex ways in which undocumented Central Americans are situated both inside and outside the United States and their countries of origin, Coutin has researched the process through which Salvadorans have attempted to redefine the legal constraints that have limited their options in the United States. She identifies a situation of "legal nonexistence" that Salvadorans (and I would argue Guatemalans, too) have experienced, which is characterized by being physically present and socially active, but lacking legal recognition. As Coutin (2000b) observes, although legal nonexistence in the United States has not precluded these immigrants' social participation and political activism, legal nonexistence is a state of sub-

${ }^{8}$ The anthropologist Leo Chavez (1991) also used Victor Turner's concept of liminality to capture the territorial passages of undocumented immigrants as they cross the border and the implications these have. Here, I also use this concept to capture this transition but highlight the consequences of an extended liminality. 
American Journal of Sociology

jugation that results in vulnerability to deportation, confinement to lowwage jobs, and the denial of basic human needs, such as access to decent housing, education, food, and health care. To be sure, nonexistence has been characterized as subversive in some contexts because those who transgress certain borders have been celebrated for the challenges they pose to established hierarchies, as reflected in the work of Liisa Malkki among refugees in Tanzania (Malkki 1995). However, in the case of Central Americans legal nonexistence can mean erasure of rights and personhood, thus making violence against people in this condition not only legitimate but sometimes even required (Coutin 2000b) and a situation in which their rights become ambiguous.

Building on Turner's concept of liminality and on Coutin's legal nonexistence, and bridging citizenship theorizing and immigrant incorporation and belonging, I examine how a condition of uncertain legality shapes social and cultural aspects of immigrants' lives and the meaning that a suspended legality or a "legal limbo" (not only nonexistence) has for them. These immediate experiences shape if and when these immigrants acquire permanent legal status and, eventually, citizenship, and as such will also be felt on their own future and the future of their children.

Thus, I would like to use the term "liminal legality" to express the temporariness of this condition, which for many Central Americans has extended indefinitely and has come to define their legal position. This "liminal legality" is characterized by its ambiguity, as it is neither an undocumented status nor a documented one, but may have the characteristics of both. Importantly, a situation of "liminal legality" is neither unidirectional nor a linear process, or even a phase from undocumented to documented status, for those who find themselves in it can return to an undocumented status when their temporary statuses end. When Central Americans are granted temporary legality, they are conferred the right to work and reside in the United States without access to social services. In some cases they are later given the opportunity to renew their permits. However, when the renewed permits expire, these immigrants slip back into the realm of nonlegality. Indeed, as Uriarte et al. (2003) observe in their Boston study, nonrenewal or denial of an application means an immediate return to undocumented status or deportation; thus, some immigrants do not apply for a temporary permit even if they are eligible. Of course, these individuals do not wait passively for their statuses to change. They look for other avenues to become permanent legal residents, such as applying for asylum (see Coutin 2000b), resorting to marriage, or seeking legalization through work, but these efforts do not always work out.

My examination questions the black-and-white conceptualizations of documented and undocumented immigration by exposing the gray area 
of "liminal legality," which may affect assimilation and belonging in important ways. Furthermore, in an era of enhanced immigration controls and increasingly rigid laws, more immigrants may find themselves in a similar gray area of legality. Consistent with immigration reforms in several immigrant-receiving countries that focus on barring immigrants from resources and benefits in society, stiffer immigration laws seek not only to reduce the number of immigrants entering the country, but also to keep more of them in undetermined legal statuses. This situation denies immigrants many rights and marginalizes them from the national community, and it is by no means unique to the cases I discuss here. As for Salvadorans and Guatemalans, even new waves of immigrants experience this situation, because there continues to be a series of temporary permits for them as well. Thus, insights from an analysis of liminal legality will have relevance not only for Central Americans but also beyond this group, as political instability increases around the world, capital and labor flow more intensely and rapidly, immigration laws in receiving countries set more difficult eligibility requirements, and temporary statuses and guestworker programs proliferate as new strategies pursued by immigrant receiving countries around the globe (see Mountz et al. 2002) to regulate and control immigrants.

Research on undocumented immigration demonstrates that an undocumented status affects directly the immigrants' job prospects and working conditions (Simon and DeLey 1984; Grasmuck 1984) as well as earnings (Chiswick 1984). . One of the consequences of the Immigration Reform and Control Act of 1986 (IRCA) is that it led to greater discrimination against undocumented migrants in general (Heyman 1998) and resulted in a steady deterioration in their wages (Phillips and Massey 1999; Massey et al. 2002). Similar to undocumented immigration, a condition of "liminal legality" not only overshadows the potential gains of individuals' higher levels of human capital but also exacerbates the effects of other systems of stratification, such as those based on social class, gender, and ethnicity. Furthermore, a liminal legal status among immigrants who would otherwise be classified as refugees (as in the case of many Guatemalans and Salvadorans) creates added obstacles, as these individuals face additional consequences resulting from the sudden uprooting of their migration and the impossibility of returning while the political conflict and violence that prompted their departure still flare in their origin countries. Thus, liminal legality shapes immigrants' incorporation and membership in the host society, but not all immigrant groups or even immigrants within the same group are affected in the same way.

${ }^{9}$ In an early study of Mexican migration, Bean, Telles, and Lowell (1987) found that the wages of such workers are not affected by their immigrant status per se. 
American Journal of Sociology

\section{CONTEXTUALIZING CENTRAL AMERICANS' RECEPTION}

This section contextualizes the Central Americans' legal experience in the United States, so that I may set the stage for discussing the three spheres of their lives I examine here. My focus is on aspects of sociocultural incorporation (e.g., bearing and raising children, establishing ties, participating in the community, creating art), but these immigrants' liminal legality greatly influences their economic opportunities as well. Even though some Salvadorans and Guatemalans with relatively higher levels of education and English language skills are employed in technical and administrative jobs, and those with lower educational levels and English language proficiency are likely working in service occupations and as operators and laborers, these are not clear-cut distinctions. Generally, those who lack a permanent legal status tend to labor in low-paying jobs that require few skills (Menjívar 2000). Among these immigrants there are many stories of former teachers working as dishwashers, former accountants taking care of other people's children, former nurses cleaning houses, former business owners cleaning office buildings at night, and college graduates looking for work as day laborers. The Central Americans' concentration in these jobs does not depend only on their legality, individual characteristics, or human capital levels but also on the jobs available at the time and place of their U.S. destination. However, given their continued uncertain legality, niches created during harsh economic times have endured and become some of these immigrants' most important, and often only, avenues for employment.

\section{U.S. Reception and Legal Status}

Central Americans have been migrating to the United States for at least 100 years, when members of the Central American elite traveled to the United States for business and pleasure (Menjívar 2000). During and after World War II, shipyards and wartime industries hired Central Americans (mainly Nicaraguans and Salvadorans recruited to work in the Panama Canal) to work in these labor-scarce industries. By 1950, Central Americans had outnumbered the Mexican-born in San Francisco, but until the 1980s they remained a small, relatively invisible group, "passing" or being mistaken for Mexicans. Massive Central American migration to the United States began in the 1980s, when several countries in the region were engulfed in political turmoil. A 12-year civil war in El Salvador and an armed conflict in Guatemala that lasted three times as long contributed to tripling and sometimes even quintupling (in the case of the Salvadorans) the number of these immigrants. The political crises that shaped these immigrants' decision to emigrate, however, did not automatically deter- 
mine their eventual arrival in the United States. Many Central Americans crossed several international borders to reach their destinations because they had family and friends already in the United States. These ties had been forged through an enduring history of U.S. political, military, economic, and cultural influence in Central America. Therefore, when the conditions in that region deteriorated to the point where many sought refuge elsewhere, the United States emerged as a preferred destination (Menjívar 2000).

Although many Salvadorans and Guatemalans who immigrated in the 1980s were fleeing violence in their countries, most were not accorded refugee status by the U.S. government but were treated as economic (mostly undocumented) immigrants, a reception more in line with U.S. policies in Central America than with the conditions of exit and the plight of these immigrants. The U.S. government could not legally recognize refugees generated by a conflict it was financially and militarily supporting, as it would have contradicted its foreign policy in that region. Central American immigrants indeed embody the contradictions of U.S. policies and politics in the Central American region. Although victims of Central America's geopolitics, these individuals have been received by the United States as depoliticized labor migrants who do not need political protection (Rodríguez 2001). As with other refugee populations in the United States, these immigrants' legal status has been shaped by the intersection of immigration and refugee policy with foreign policy. But unlike de jure refugees, these de facto refugees have been trapped in a situation that reflects the dynamics of U.S. policy in Central America. Their case makes evident that defining a particular group of immigrants as refugees is not based solely on unsafe conditions in the origin country, but even more important, on the fact that a receiving state recognizes them as deserving asylum and assistance (Zolberg, Suhrke, and Aguayo 1989), a decision based on international political considerations.

Also, U.S. immigration law has been applied unevenly across Central American groups and within the same group at different points in time, contributing to discrepancies in the experiences of Central Americans. Thus, for over two decades the web of legal obstacles and undecipherable and intractable immigration laws and deadlines has made legality paramount in the Central Americans' lives, particularly when a return to their origin countries has been either life threatening or economically unfeasible. Moreover, increasingly rigid immigration laws make it almost impossible to obtain a U.S. tourist visa in their origin countries.

Without a visa, many Central Americans have had to cross two or three international borders clandestinely. These journeys by land have left many of them even more traumatized than the conditions they fled. Traveling by land often involves complicated arrangements with coyotes (smug- 


\section{American Journal of Sociology}

glers), as well as robberies, assaults, and extortion by local authorities along the way. The journey north turns out to be so lengthy and costly that upon arrival in the United States many of these immigrants are emotionally and physically scarred and must also face huge debts that they must repay to cash-strapped relatives (Mahler 1995; Menjívar 2000). Because many Salvadorans and Guatemalans are in the process of applying for the different forms of legal protection, they also cannot leave the country easily without risking the ability to return. Rodríguez (2002a) refers to these immigrants' hardships during the trip specifically as $e x$ periencias fronterizas centroamericanas, or Central American border experiences, and argues that Central American immigrants personify the (un)sung heroes of legendary border crossing (Rodríguez 2001, p. 387). A Salvadoran man I interviewed in Washington, D.C., compared his situation to that of Mexican immigrants: "If Mexicans are deported, they go to their own country, and manage to come back more easily. If we are deported, we end up in the hands of robbers and Mexican authorities, which is worse than the [U.S. INS] migra because there everything is bribes." A Mexican woman in Phoenix corroborated this point: "I understand the poor Guatemalans. If they get deported, válgame Dios [God save me], it's a thousand times more difficult to get back. So if they come here, that's it, they're stuck, they can't think of going back in a long time."

Notwithstanding legal barriers, many Central Americans have continued to enter the United States. Salvadorans and Guatemalans who arrived in the United States prior to January 1, 1982-the cutoff point to apply for amnesty under the IRCA-applied for this benefit (Menjívar 2000). However, fewer than half of Salvadorans and Guatemalans arrived prior to that deadline. The thousands who arrived at the height of the political conflicts in their countries in the 1980s were ineligible for this provision. Once on U.S. soil, Salvadorans and Guatemalans could apply for political asylum, but historically they did not fare well in obtaining it. Throughout the 1980s less than 3\% of these applicants were granted such status. Immigrants' rights groups lobbied on behalf of the Guatemalans and Salvadorans, and eventually, in 1990, Congress granted temporary protected status (TPS) from deportation to all Salvadorans who arrived prior to September $19,1990 .{ }^{10}$ TPS can be granted to aliens who are temporarily

\footnotetext{
${ }^{10}$ The granting of TPS for Salvadorans can be attributed to intense lobbying by religious and community organizations, but also to the efforts of different Salvadoran presidents who asked the U.S. government not to deport Salvadoran citizens, as their remittances have been the backbone of the Salvadoran economy during and after the war years. Such lobbying put these heads of state in the rather unusual position of asking a foreign state to take in and protect their citizens. In a similarly odd act, the Salvadoran government makes available consular services to aid Salvadorans in preparing their TPS applications.
} 
unable to return to their home countries due to a political conflict or natural disaster. ${ }^{11}$ The U.S. government only began granting TPS to Salvadorans toward the end of the Salvadoran civil conflict in January 1992, a move that further exposes the deep links between foreign policy and immigration and refugee admissions. This dispensation was not extended to Guatemalans because they were not deemed as deserving of this protection, even though the U.S. State Department had noted on different occasions the disastrous human rights record of the Guatemalan government and the severity of the political conflict there.

TPS allowed Salvadorans to live and work in the United States for a period of 18 months, and approximately 187,000 applied for this dispensation. In June 1992, TPS rolled into deferred enforced departure (DED), a dispensation (designated by the Office of the President) that ended in December 1994 but was extended until September 1995 when it ended for good. Fewer Salvadorans resubmitted applications for this extension. Some had changed their status to permanent residents, but others found the application process confusing and reliable information hard to obtain, particularly because the name of the dispensation changed. TPS and DED granted neither asylum nor refugee status, and the only privileges obtained were a work permit and suspension of deportation for the duration of the dispensations. Also in 1990, as a result of the settlement of a class action suit (American Baptist Churches v. Thornburgh [hereafter, $\mathrm{ABC}]$ ) that alleged discrimination against Guatemalans and Salvadorans on the part of the Immigration and Naturalization Service (INS), Salvadorans and Guatemalans were allowed to resubmit asylum applications. Initially the success rate of applications increased to $28 \%$ for Salvadorans and $18 \%$ for Guatemalans in 1992 (National Asylum Study Project 1992) but has since leveled off and declined.

Some Salvadorans and Guatemalans were included as beneficiaries of the 1997 Nicaraguan Adjustment and Central American Relief Act (NACARA). ${ }^{12}$ Salvadorans who entered the country before September 19, 1990, and Guatemalans who entered before October 1, 1990, and registered under the $\mathrm{ABC}$ settlement, or who had filed an asylum application before April 1, 1990, could be granted a "cancellation of removal" (cancellation of deportation) (Menjívar 2000). NACARA confers a work permit to Guatemalans and Salvadorans, but obtaining this status requires filing

${ }^{11}$ The U.S. attorney general had the authority to designate a country for TPS, but as of March 2003, when the INS was reorganized and transferred to the Office of Homeland Security, this authority now rests with the Secretary of Homeland Security.

${ }^{12}$ NACARA is another example of the deep links between immigration and foreign policy. The countries designated for this benefit (in addition to Nicaragua, Guatemala, and El Salvador) are Cuba and those of the former Soviet bloc. Some argue that this act was designed to deal with remnants of Cold War policy. 


\section{American Journal of Sociology}

a renewal form and paying a fee once a year as it is renewed. Salvadorans and Guatemalans already placed in deportation procedures are required to appear before an immigration judge. They can then request a cancellation of removal, and their immigration status will be later readjusted to that of a permanent resident. They must prove seven years of continuous residence in the United States, good moral character, and that a return to their countries would result in extreme hardship to them or to their spouse, child, or parent who is a U.S. citizen or permanent resident. Immigrant rights groups have lobbied on behalf of the Salvadorans and Guatemalans so that the benefits NACARA confers to other nationals included in this act-adjustment to legal permanent residence without a hearing on a case-by-case basis-would also be extended to them. However, in October 1998 (as well as in subsequent years), Congress denied this request. And the prospects of obtaining full NACARA benefits have decreased sharply with further tightening in immigration law after September 11, 2001.

Although the civil conflicts in Central America officially ended in 1992 in El Salvador and in 1996 in Guatemala, immigration from the region to the United States has continued. The structures of inequality behind both the civil conflicts and massive migration are still in place, and now many Central Americans face high levels of violence associated with"common" crime. Many former soldiers found themselves unemployed at the end of the conflicts but had access to weapons and were lured into the gangs established by youngsters deported from the United States. ${ }^{13}$ Now membership in gangs in Central America has grown exponentially (many of the new recruits are no longer former soldiers), and associated crime is rampant. As has occurred in other postconflict contexts, the political violence of the past has been transformed into other forms of violence, often called "common" crime. The local economies do not offer many opportunities, and trends of inequality have widened. Moreover, in spite of improved economic growth rates, both countries have high levels of unemployment and underemployment. Thus, there are ripe structural and social conditions in these origin countries for continued U.S.-bound migration. At the same time, the channels through which many Central Americans migrated have expanded and become more sophisticated, as more and more people have relatives and friends in the United States, and "each act of migration alters the social context within

\footnotetext{
${ }^{13}$ Since the mid-1980s, Central American youths who have been in trouble with the law have been deported to their countries of origin. In the context of war and postwar conditions, with limited access to resources and employment, they have found fertile ground to create the gangs to which they had belonged in the United States (even using the same names).
} 
which migration decisions are made, thus increasing the likelihood of additional movement" (Massey et al. 2002, p. 20). Also, El Salvador suffered two devastating earthquakes in early 2001 that exacerbated many of the problems left by the years of civil war. The United States granted TPS for a period of nine months starting in March 2001 to those Salvadorans who arrived following the disasters. This dispensation already has been extended a few times and at the time of this writing will expire in September 2006. Approximately 263,000 Salvadorans applied for this TPS and are eligible to benefit from the extension. Again, this is temporary relief-with forms, fingerprinting, photos, fees, and proofs of residence every time it is renewed-not permanent status. Furthermore, one must bear in mind that the Central Americans' legal circumstances are embedded in a larger framework of stiffer immigration law. Thus, the Illegal Immigration Reform and Immigrant Responsibility Act (IIRIRA) of 1996 also affects the lives of Central Americans, particularly their families, both in the United States and in their origin countries (see Rodriguez and Hagan 2004). ${ }^{14}$ Unfortunately, due to size of the INS bureaucracy and its huge backlogs, applications take several years to be processed, and often an individual's record is lost and the process must start again. For example, the backlog to process change of address forms alone takes two years. All of this means that a large proportion of Salvadoran and Guatemalan immigrants have been and remain in the United States in a state of liminal legality. The INS estimated that close to $60 \%$ of Salvadorans and Guatemalans were undocumented or protected only temporarily (INS 1997), and Lopez, Popkin, and Telles (1996, p. 287) calculate this proportion to be $49 \%$.

Thus, the Salvadorans' and Guatemalans' position vis-à-vis immigration law has translated into a legal limbo, for sometimes they are protected by temporary amnesties with multiple deadlines that apply to certain individuals but not to others, even if they are members of the same family. Immigration law has effectively produced a population of longtime residents with suspended lives. At the same time, their countries do not offer any real opportunities if these immigrants were to return because they still suffer the social and economic consequences of decades of civil wars. The Central Americans' situation differs from that of being simply undocumented in that the series of temporary permits that continues today, the ups and downs in the acceptance rates of asylum applications, and

${ }^{14}$ IIRIRA expanded the range of crimes that make noncitizens ineligible for permanent legal residence and permanent legal residents deportable, increased border control efforts, eliminated waivers through which convicted noncitizens could petition to remain in the United States, and made it more difficult for undocumented immigrants to obtain permanent legal residence. 


\section{American Journal of Sociology}

the lengthy adjudications of $\mathrm{ABC}$ and NACARA benefits have given them the illusion and hope that they will become permanent residents if they only wait a little longer. ${ }^{15}$ Those who were granted TPS in 1990 believed that this status would become permanent when it was extended into DED, but it ended, apparently permanently, in 1995. The ABC cases began to be adjudicated in 1998, and those who applied for NACARA are still waiting for their cases to be adjudicated. Often individuals apply for the multiple dispensations, like ABC and NACARA, in hopes that one will eventually materialize into permanent status. In a study of Central American immigration conducted in Boston, Uriarte et al. (2003) found that at the center of the most pressing issue-legal status-were the difficulties and lengthy process that those who are eligible for legalization programs face. And the process itself is fraught with anxiety-especially around expiration and renewal time-because any wrong step, missed deadline, lack of information, or an error on a form may result in denial and deportation (Uriarte et al. 2003, pp. 37-38). Meanwhile, immigrants must plan out their lives, their marriages, their children's lives, and make a host of other short- and long-term decisions. Thus, it is precisely this aspect of their condition - their extended liminal legality - exacerbated by the trauma of their emigration, that has reverberated to multiple aspects of their lives.

\section{FAMILY, SOCIAL NETWORKS, THE CHURCH, AND CULTURAL PRODUCTION}

The Guatemalans' and Salvadorans' liminal legality and the multiple deadlines, requirements, and misunderstandings associated with their status have affected their lives in multiple ways. Many cannot leave the United States because they have filed an application for a dispensation or have only temporary protection and risk losing it by traveling abroad, particularly given current border enforcement practices (see Massey et al. 2002). ${ }^{16}$

The perpetual legal limbo in which many live is manifested in the three areas I have selected to discuss here. Surely these are not the only areas

\footnotetext{
${ }^{15}$ In no way do I imply that one of these legal statuses is necessarily "better" than another (e.g., liminal legality vs. being outright undocumented). I am, however, underscoring the gray area in legal statuses that is increasingly becoming more relevant to examine analytically.

${ }^{16}$ Indeed, as Massey et al. (2002, p. 129) have noted recently, an unintended consequence of the current border buildup has been longer trip durations, lower probabilities of return migration, and a shift toward permanent settlement, thus increasing the number of undocumented who stay in the United States.
} 
of the immigrants' lives that are affected,${ }^{17}$ but they illustrate the range of the effect that a liminal legality has on these immigrants for they include the immediate family and social networks, the community level of religious institutions, and the broader area of artistic expression. To highlight my points I will rely on data I collected through extensive fieldwork from late 1989 through 2001 among Salvadorans in San Francisco, Washington, D.C., and Phoenix, and among Guatemalans in Los Angeles and Phoenix, complemented with interviews with other Latin American-origin immigrants in Phoenix. The data from San Francisco include ethnographic fieldwork in the Salvadoran community from late 1989 to 1994, 50 indepth interviews, and a survey of 150 respondents. I collected data in Los Angeles from 1994 to 1995 that contains ethnographic observations and 26 in-depth interviews with Guatemalan immigrant women. The data from Washington, D.C., were gathered between 1996 and 1997, and come from qualitative observations, 25 intensive interviews, and a survey of 87 Salvadoran respondents. The data from Phoenix come from qualitative field research conducted between 1998 and 2001, where 25 Salvadorans and 14 Guatemalans were interviewed (for further details see my earlier work [Menjívar 1999a, 1999b, 2000, 2001]).

The examination of these immigrants' experiences in these different sites is central for my argument. San Francisco is a well-established receiving area for Salvadorans and the city with the longest continuous history of Salvadoran migration to the United States (Menjivar 2000). Los Angeles is home to the largest concentrations of both Salvadorans and Guatemalans in the United States. Washington, D.C., is a relatively new destination point for Salvadorans; the majority arrived in the past two decades. Yet Washington is the only U.S. city where Salvadorans make up (a slight) majority of the Latino population. Finally, Phoenix is one of the newest points of destination for both groups-the majority having arrived either directly from their countries or from California in the 1990s - and they constitute a minority of the Latino population. These diverse local configurations could result in different experiences of legal uncertainty. However, immigration law is created at the federal level and thus it is constant in all destination points. Thus, whether the study's aim was to understand immigrants' social networks (as was the case in the study in San Francisco), women's informal ties (as in Los Angeles), religious participation (as in Washington, D.C.), or an exploratory study

\footnotetext{
${ }^{17}$ For instance, Rodriguez (2003) notes that Maya Guatemalans who cannot travel to Guatemala are unable to participate in certain religious ceremonies that require travel there (such as burying their dead) and that this restriction in turn prevents them from fulfilling important cultural obligations.
} 


\section{American Journal of Sociology}

of Latin American-origin immigration (as in Phoenix), the immigrants' ambivalent legal status emerged as a vital factor shaping their lives.

Family and Social Networks

Among immigrants living in liminal legality, family separations resulting from migration can be indefinite. To be sure, migration is also accompanied by separation among other immigrants, as the migration process itself is often characterized by a transitional phase whereby one family member comes to work in the United States and the rest of the family stays in the home country (see Briody 1987). However, what might be a temporary disruption among other groups has turned into a permanent situation for many Central Americans. Many live with the hope that their temporary permits will become permanent, that their asylum, $\mathrm{ABC}$, or NACARA applications will soon be approved, or that there will be another temporary protected status or perhaps an amnesty that will guarantee them the right to live and work permanently in the United States. Eternally waiting to regularize their status and with trips back home physically and economically costly, they put off family reunifications indefinitely, with serious consequences for all involved. ${ }^{18}$

A temporary status restricts international travel; individuals in this situation need permission to reenter the United States (advance parole) after traveling abroad. Their application for a travel document (with forms, photos, and fees) must be approved before leaving the United States; otherwise they risk termination of their pending applications. When a person needs to travel on short notice, this requirement makes such a trip nearly impossible. A comparison with Mexican undocumented immigrants is useful here. Until recently, a feature of Mexican undocumented migration was these immigrants' mobility across the border. Mexicans have been known for visiting their origin communities regularly, particularly during holidays, to marry, as well as to visit family (see Hirsch 2003; Massey et al. 2002). Interviews I conducted in Phoenix among Mexicans corroborate this observation, for several immigrants mentioned that not much time goes by without seeing relatives in Mexico. "I always visit, or they come here sometimes, but I can't go on without seeing the faces of my family. When it has already been a year I feel a need to see them and I go, no matter what," said an undocumented Mexican woman, a situation that might change as the militarization of the southern border continues and interferes with the immigrants' wishes. Salvadorans have

${ }^{18}$ A report by the Canadian Council on Refugees (2004) on delays in family reunification finds that separations of three to four years are dangerous and pose serious harm for families. 
engaged in back-and-forth travel, but this is more common among business owners and courier services who cater to individuals and families at both ends, in which case the difficulty to travel for many has become lucrative for a few (Landolt, Autler, and Baires 1999; Menjívar 2000).

Some Guatemalans and Salvadorans have come to the United States single and have established families here; others have arrived alone but have left their families back home. Some of those with families back home have established new families here. In the face of constrained avenues for legalization, Central Americans sometimes turn to marrying U.S. citizens or permanent residents in the hope of obtaining permanent legal status; in some cases such marriages become "real" ones and lead to the rupture of a previous union, but in as many cases such unions fail and legalization never materializes. A Salvadoran woman I interviewed in San Francisco was in her fourth marriage-two of them to gain legalization and two "for love" as she put it-but her legal status was still in limbo, and her political asylum application had been turned down. As her fourth marriage turned sour she applied for and obtained TPS though she knew well this was only a "temporary cure."

Many Central Americans could not bring their children with them because traveling undocumented and by land was far too dangerous. Some, having brought their children, sent them home after seeing the high crime rates and ubiquity of drugs in the neighborhoods where they settled (Miller Matthei and Smith 1998; Menjívar 2000, 2002a). ${ }^{19}$ In other cases, the youngsters have been deported. ${ }^{20}$ Children who stay behind or are sent back home live in the care of other relatives while their parent (or parents) labor(s) in the United States to send them money for the necessities of life. Although the material and financial lot of these children (and their relatives) improves when they receive money and gifts from the United States, this betterment does not come without a price (see Hondagneu-Sotelo and Avila 1997). The unstable legal status of many of these families and their still precarious financial situation make it difficult to see each other regularly or to reunite permanently. ${ }^{21}$ Moreover, the possibility of an imminent deportation affects their long-term plans as well. As other parents commented, a Guatemalan woman in Los Angeles

${ }^{19}$ This practice might change, as the levels of violence in their countries of origin continue to escalate and might be even higher than those in urban America.

${ }^{20}$ For an in-depth examination of the lives of these deportees, see Rodríguez and Hagan (2004).

${ }^{21}$ I would like to echo Gamburd (2000), who notes that while discussing the negative consequences that immigration has for families, it becomes easy to blame "family breakdown" on migration, disregarding the structural conditions that give rise to migration in the first place and, I would add, the legal constraints that prevent family members from being together. 


\section{American Journal of Sociology}

said that even though it was painful to be separated from her children, she had decided to send them back. In case she was deported, she did not want the children to go to a detention center alone for an indefinite period, as she had heard could happen to families that are deported. ${ }^{22} \mathrm{~A}$ tactic that immigration officials use to get people to sign deportation documents is to separate family members and to tell one spouse that the other has already signed a request for voluntary departure. And a Salvadoran mother in Oregon wanted to put up for adoption her 12-yearold son in hopes of improving his chances of staying in the United States, as she had had temporary protected status for over 10 years and was unsure whether it would eventually become permanent. The boy had lived in El Salvador with his grandmother, and he had traveled to the United States alone at age 10 to be reunited with his mother (Wright 2005).

Family separations are originally meant to be temporary, but they often extend for indefinite periods due to the immigrants' uncertain situation. Many Central Americans left their homes at a moment's notice expecting to return immediately after the conflict ended. But the forces of resettlement are strong and their origin countries have little to offer. Thus, many immigrants stay put and live with the illusion that they will become legal permanent residents, so they can travel to visit loved ones or bring them over through family reunification. ${ }^{23}$ During these separations no one is exactly sure of when or how they will reunite. When they finally meet again, the parents and children often find little semblance of a family in each other and sometimes cannot even recognize each other physically. A Salvadoran woman I interviewed in San Francisco laughed endlessly when she told me about her encounter with her son, whom she had left a child in El Salvador and had not seen in 10 years. When she went to meet him at a coyote's house in Los Angeles, she kissed and hugged the wrong man because she could no longer recognize her own son. And in Phoenix, after obtaining his permanent residence, a Salvadoran man decided to travel to his country, but he first asked for photographs and videos of his family there as he prepared for his first trip in 17 years: "I don't want to go home with the wrong family from the airport! I have heard that bandits wait for distracted and excited visitors to rob them

\footnotetext{
${ }^{22}$ According to Department of Homeland Security officials there are hundreds of thousands of parents and children who have been separated as a result of enforcing the 1996 Immigration Act, which all but eliminated the discretion of immigration officers to consider family ties before enforcing an order of removal. Officials often refer to it as a "Sophie's choice situation" and it occurs among immigrants of different nationalities (Bernstein 2004).

${ }^{23}$ Permanent residence for many of these immigrants means the possibility to travel to their home countries more frequently (Coutin 2000a; Menjívar 2002a).
} 
blind. And to be sincere with you, Cecilia, I don't remember what they [the family] look like. If I didn't know they're my family, they would be like complete strangers to me."

The lengthy separations between parents and children also create tension when they are reunited (Menjívar 2000). Leslie (1993) observes that family reunification for Central Americans can be problematic because of the unrealistic expectations that the parents and the children have of each other. The children often reproach the parents for having left them "abandoned" for too long. A young woman I interviewed in San Francisco, who had come to join her mother after not seeing her in several years, explained:

My mother is very upset at me all the time. What can I do? I don't even call her mamá. I call my grandmother in El Salvador, with whom I grew up, mamá. I call my real mother by her first name. Just because we see each other again doesn't mean, “oh yes, let's hug each other.” She's like an aunt or something like that to me. I don't have the confianza [trust] to ask her for something or to confide in her. I feel better with my aunt, who used to live with me in El Salvador (Menjívar 2000, p. 129).

Not only had this young woman grown up hearing people refer to her mother by her first name, but, she said: "I hardly know this lady and she wants me to call her mamá. One should reserve that word for the person who's been a mother." Other times the children, accustomed to the material goods financed by the parents' labor in the United States, demand the same when they join the parents, but the parents often cannot provide these material goods because having the children in the United States means substantial additional expenses (Menjívar 2000). And in some cases, children who are sent back or who were left in their home countries opt for migrating on their own to be with their parent or parents. It has been noted that the great majority of children entering the United States alone through the southern border are Central Americans, not Mexicans (Howley 2005), which highlights family separations among Central Americans.

Some Guatemalans and Salvadorans have tried to keep a sense of family, developing novel ways to stay connected with loved ones back home. With limited ability to travel, they have communicated through telephone, family, friends, letters, and even video conferencing. Some of the Guatemalans I met in Los Angeles even synchronized an event such as a birthday celebration, so that physical distance would not attenuate the family's efforts to remain connected. Thus, at least during their time of separation, these families may be more inclined to develop and maintain transnational links. However, such efforts cannot simply be celebrated as part of these immigrants' enduring links with their communities of origin, but should be tempered by the numerous costs and the anxiety, dislocation, 


\section{American Journal of Sociology}

and alienation that such separations often produce (Menjívar 2002a). A Salvadoran woman in San Francisco explained what it feels like to be separated from her two older sons without being able to travel to see them. Her TPS and asylum applications have taken over a decade to process, and she still could not travel because she was afraid she would be unable to return. In her words:

I live angustiada [anguished] because I don't know if they eat or not, if they are clothed or not, if they get sick, will they get good treatment? [her voice breaking] It's the most horrible torture for a human being, not knowing how your children are, if they're suffering. Sometimes I want to abandon everything and go home to see my boys. But then I think, I have a daughter here too and I have put up with this life for a while already, so I better stay put, so that they can, God willing, benefit more in the future. It's my only consolation. (Menjívar 2000, p. 210).

Other times, family reunifications do not work out smoothly because the new families that have been formed in the United States, particularly the step- and half-sibling combinations, do not always get along. During lengthy and uncertain separations it is not uncommon for Central Americans to form new unions in the United States, mostly acompañandose (cohabiting) with partners who themselves have children from previous unions. Problems arising from these new family formations are sometimes exacerbated when newcomers come to join relatives in overcrowded homes (Menjívar 2000), living conditions that are common among many poor Central Americans. It is noteworthy that the women and men in the U.S.-established unions are often responsible for their own families in their countries of origin and, therefore, are more likely to keep earnings and expenditures separate. In these cases, the women feel that it is imperative to earn their own incomes in order to spend them as they please, mostly to support their own families back home (Menjívar 1999a). A Guatemalan woman I interviewed in Los Angeles works seven days a week cleaning houses because she needed to work to meet her responsibilities for her children back home: "I can't stop working even if my husband works because if he supports me I won't be able to send money to my children. Besides, he can't give me enough money because he has his own family to support. If both of us work, both of us can dispose of money and do with it whatever one pleases. It'd be different if we only had one family, but we really have three families to support and because we're poor, we need to work more" (Menjívar 1999a, p. 614).

In addition to family separations, a liminal legality has other effects on family members who are in the United States, particularly on the children, with the potential to affect their future. For instance, the uncertain legal status of many Guatemalans and Salvadorans precludes them from ob- 
taining an education that could help them to advance socioeconomically. Although immigration status itself is not a barrier to access K-12 education, it does present an obstacle to higher education; most colleges and universities require that students be permanent legal residents or citizens in order to obtain in-state tuition and to qualify for student loans and other financial aid. Therefore, many youngsters with uncertain legal statuses cannot further their education and are left with only a high school diploma, even when they are academically strong. Sometimes the children are U.S. citizens but their parents are not; to qualify for financial aid students must present extensive information about their parents' status and sources of income. Many parents who are not fully documented avoid providing this information for fear of being deported when their permits expire. Options for advancement, therefore, stop abruptly when these youngsters finish high school, and a high school diploma is certainly not a key to success in today's U.S. labor market.

I would also like to note the deleterious effects of these immigrants' liminal legality on their social and kin networks. Guatemalans and Salvadorans usually borrow from friends and family to make the expensive trip north, which can easily cost at least three times as much as travel for Mexicans due to the greater geographical distance. Upon arrival, already indebted to family and friends, they must take low-paying jobs with no security and earn wages that are not enough even to support themselves. Elsewhere (Menjívar 2000, 1997) I have documented how precarious living conditions affect exchanges among these immigrants. With scant material resources and legal entanglements with no end in sight, they end up with little to share with others, and their networks sometimes weaken. In these cases reciprocity and norms of exchange are difficult to uphold because people do not have enough even for themselves, much less to help others, as cultural norms and expectations would dictate (Menjívar 2000). I have observed similar situations among Guatemalans in Los Angeles and Phoenix as well. In the Guatemalan case, however, "internal ethnicity" (Bozorgmehr 1997) further complicates the picture, as Maya and Ladino Guatemalans rarely seek out one another for support (Menjívar 2002b). This situation reflects interethnic relations in Guatemala, which are rooted in an ideology that has placed Ladinos in a superior position to the indigenous since colonial times. Nonetheless, for both Maya and Ladino Guatemalans, as well as for Salvadorans, the material and physical conditions-shaped largely by the immigration laws that govern their lives-have deeply affected the dynamics of their social networks. 
American Journal of Sociology

The Church in the Immigrants' Lives

Sometimes the relatives who await Central American newcomers do not have the resources to help them, and the newly arrived must procure assistance from others around them. One of the most important spaces for Salvadorans and Guatemalans to obtain varied forms of assistance and to connect with others is the church, a situation that is intimately linked to the immigrants' marginal legality (Menjívar 2003). Religious institutions have been highly significant for immigrants-past and present, an idea that lies at the core of the sociological study of immigration and religion (Warner 1998, p. 15). In the case of Central Americans, religious congregations have been central; the Catholic Church and mainline Protestant denominations have offered these immigrants the assistance and protection that the U.S. government has refused to extend to them or that their relatives cannot provide. Basing their actions on religious teachings, faith-based workers have filled the vacuum of government assistance for these immigrants and have been actively involved in improving their lives. In the 1980s they created sanctuaries throughout the country to protect them from deportation to life-threatening conditions in their homelands, and religious groups were pivotal in championing the legal struggle that eventually conferred temporary protected status to Salvadorans and gave both groups an opportunity to resubmit asylum applications. Since the initial years of massive Central American migration these workers have provided settlement assistance, opened up community clinics, and developed English-language and vocational classes. In addition, they have issued pastoral calls to remind their congregations to welcome immigrants into their communities. Faith-based workers also have taken a stand against restrictive immigration laws and have spoken out on the harmful effects that these laws might have on the immigrants (Menjívar 2003). Religious congregations also have created infrastructures to help Central Americans to apply for the multiple legal dispensations, track application deadlines, and make sense of the conundrums that have accompanied these immigrants' legality.

Although evangelical (mostly Pentecostal) churches have not created a similar infrastructure of support and lack the institutional organization that permits larger congregations to coordinate efforts at national and even international levels, they too have played a central role in the immigrants' lives (Menjívar 1999b, 2001, 2003). In this case, newcomers themselves have established churches and have opened up their new temples to welcome their brothers and sisters in need. Thus, religious institutions have been pivotal in easing the anxiety of these immigrants' legal limbo. The relationship of the Central Americans with religious institutions, therefore, will likely differ from that of other contemporary 
immigrants (Menjívar 2001, 2003). ${ }^{24}$ Indeed, the Central Americans' experiences are perhaps more similar to those of the preformalized refugee programs, a time when no government resettlement aid was available, and it was the church that provided assistance for newcomers in need. As such, religious institutions will likely play a central role in these immigrants' incorporation and eventual participation as full members of society (through permanent legality and then as citizens).

Not surprisingly, Salvadorans and Guatemalans in all the sites where I have conducted fieldwork brought up the importance of the church in their lives. ${ }^{25}$ They often traveled long distances to get to their places of worship and did not hesitate to explain how the church helped them in their daily lives. In my conversations with them, they emphasized that help from the church should be not only spiritual or moral but also material and financial, because they have no other institutional sources for this assistance. A Salvadoran woman in Phoenix commented, "Yes, I think the church should help. If not the church, who else? There are many people who need food, clothes, and the church can assist those who are in most need because there is no one else we can turn to for help." Also in Phoenix a former Salvadoran soldier commented: "I come to church every week. They help everyone with all sorts of things. Sometimes you don't have money to pay the rent or a bill or you need clothes or shoes, they help you with that here. This is the only place where you can find this kind of help" (Menjívar 2001, p. 81).

The centrality of the church's support for Salvadorans and Guatemalans is perhaps better illustrated through a comparison. In a study of Latin American-origin immigrants in Phoenix, I asked immigrants if and how the church had helped them in their lives (Menjívar 2001). Cubanswho automatically qualify to enter the country legally and have obtained a generous resettlement package- had received spiritual and moral support from the church. The Central Americans said that they had been offered, in addition to this kind of help, material and financial assistance. For a Cuban man, this is how attending a Lutheran church had helped him:

When I arrived here, I sought the church. When I was depressed, I would

\footnotetext{
${ }^{24}$ The point is not that Central Americans will be more or less religious than other immigrants, but that their relationship with and perception of the church will be different (see Menjívar 2001, 2003). For instance, in my study in Phoenix (Menjívar 2001, 2003), Central Americans regarded religious institutions as more central to their lives than Mexicans and Cubans did.

${ }^{25} \mathrm{In}$ an inductive fashion, it was the immigrants in San Francisco who called my attention to the importance of the church for them, an aspect of immigrant life that I have examined ever since.
} 


\section{American Journal of Sociology}

go to church. Yes, I have found support in the church; it's been spiritual support. The pastor has been nice to me, he's been very patient, and he's even visited me here at home. We have talked a lot. Having a person who listens is sometimes what you need the most. So, yes, you can find a lot of support by going to church. (Menjívar 2001, p. 80)

In contrast, here is how a Guatemalan woman in the same church saw the church's assistance:

I think that the church is in a position to help people in need. [It helps] with clothes, things like that, but also through prayer. I have received help, lots of help, because the pastor and his son call us just to ask how we are. Sometimes they give us beans, rice, clothes for the children, a toy [for the children] here and there, like that. Sometimes they help with rent. Other times they just call us on the phone, and we talk. So, yes, I find support in my church. (Menjívar 2001, p. 80)

Some Central Americans even frequented churches of different denominations simply because they had found support in more than one congregation. For instance, a Salvadoran woman in San Francisco attended both a Catholic and a Southern Baptist church because in both she had received the help she could not obtain elsewhere, such as food, clothing, and loans of money. Therefore, religious institutions take on a more fundamental role for Central Americans, by providing them with vital assistance that ranges from legal counsel for the multiple dispensations and applications to financial support to pay for a month's rent, from organizational strategies to deal with problems in their neighborhoods to a kind word in a desperate moment. Indeed, my observations in San Francisco, Los Angeles, Washington, D.C., and Phoenix indicate that religious institutions are focal points in the lives of many Salvadorans and Guatemalans, regardless of the locality where they live. A Salvadoran man in Washington, D.C., observed: "The church has been central in our lives in many ways. Where else would you go to ask God for a favor and at the same time fix your papers? . . It's also the symbolism. Symbolically, it's been important what the church did with the Sanctuary movement. It was the biggest thing for us Central Americans fearing deportation to a certain death. To give you a place to eat and sleep where no one can touch you, deport you."

Thus, independent of the community dynamics in specific locations, religious institutions have been vital for Guatemalan and Salvadoran immigrants as they have helped to mitigate the detrimental effects of their liminal legality. More important, this situation may have long-term consequences for the immigrants' incorporation. In preliminary findings, Cadge and Ecklund (in press) note that church assistance to immigrants may serve more as a buffer from society than as a vehicle of incorporation. 
Additionally, through the church these immigrants often are able to remain connected to their communities of origin (particularly important when they cannot travel there easily), as churches create institutional spaces that connect them with loved ones back home (Menjívar 1999b; Popkin 1999). Churches create these links to different degrees, with some, particularly the ethnically homogenous and relatively smaller ones, establishing such close links between sister churches in the origin countries and in the United States that their members feel like they belong to a single congregation. A Salvadoran woman in Washington, D.C., and a member of one of these churches, told me: "We are related with the church there [in El Salvador] spiritually and in practice. We are oriented to them and they are to us. It's like one [church] in two places" (Menjívar 1999b, p. 605). The pastor of this church, who originated in the same community in El Salvador where most in his congregation came from, had created a two-hour radio program three times a week that was transmitted to neighboring states as well as to El Salvador. The congregation at both ends could listen to the same sermons and readings of the liturgy. This was important for this congregation, the majority of whom could not travel to see their families due to their legal entanglements and financial constraints.

\section{Artistic Expression}

In spite of the many adversities and challenges they face, one must not lose sight of the Central Americans' resilience, for many are contributing meaningfully and in diverse forms to their communities, schools, and families. Central American writers, filmmakers, musicians, painters, and poets-some born and raised in their countries of origin, some in the United States, and others having arrived at young ages-are actively enriching Latino cultural expressions and contributing to the national U.S. community from their specific social locations. Some are capturing in their art particular historical events and in doing so help to recuperate a collective memory that provides the generations born or raised in the United States with a fragment of their own history. Characters in novels and in short stories often embody Central American immigrants' experiences, as they express the perennial state of ambiguity and liminality in which these immigrants still live. These immigrants' liminal legality is, of course, not the only aspect of their lives reflected in their artistic expressions. Indeed, the literary production of young Guatemalans and Salvadorans who were born or raised in the United States also touches on issues of identity, on the difficult lives in the cities in which they live, and on intrafamilial relations (see Hernández-Linares 2002; Morales 2001; Epicentroamerica 2001). My point here is that liminal legality is also prominently reflected 


\section{American Journal of Sociology}

in the immigrants' artistic expressions, especially among those who emigrated as adults (the immigrant generation), and thus shapes these immigrants' particular forms of participation in society.

The Massacre of El Mozote, one of the most gruesome episodes of the Salvadoran civil war, has been reproduced in a musical composition and in a film entitled Homeland (Rodríguez 2002b). The protagonist escaped the war in El Salvador and has lived all his life in New York, but as with many of his compatriots in real life, he is still in legal limbo, and when he gets involved with a gang he is eventually deported to a land he hardly knows. Salvadoran cultural critic Ana Patricia Rodríguez (2002b) argues that this character is the incarnation of the Central American immigrant, as his situation expresses the perennial state of ambiguity and liminality in which they still live after more than two decades. Furthermore, these expressions inscribe onto a larger canvas the traumatic memories associated with Central America's recent history, a history that many immigrants still carry with them and will pass on to their children.

Some artists capture more generally the Central Americans' experience of living in legal limbo, lengthy family separations, memories of violence, of having lost their homes and sometimes their relatives in the armed conflicts, and of a harsh settlement in the United States. The musical production of other immigrants, for example Mexicans, also expresses nostalgia for loved ones in Mexico and for Mexico itself, but it is also infused with other, often romantic, themes. ${ }^{26}$ That of Central American artists tends to reflect their compatriots' experiences. Indeed, a song that a popular Mexican group (Los Tigres del Norte) wrote for Salvadorans is entitled "Tres veces mojado" ("Three Times a Wetback") and chronicles the penuries of Salvadoran immigration, which, in the eyes of this musical group, are Salvadoran specific.

The musical production of the Salvadoran group "Lilo González y los de la Mt. Pleasant" recounts the experiences of Central American immigrants in the Washington, D.C., area in songs such as "Amor sin papeles" ("Love without Documents" or "Undocumented Love"). The lyrics of "Amor sin papeles," for instance, express the legal uncertainty of these immigrants' lives and the expectation of deportation at any moment (my translation):

Si me deportan

If I am deported

\footnotetext{
${ }^{26}$ Here I refer specifically to the songs written and sung by Central Americans, not the popular songs that they listen to and dance to. Central American immigrants tend to listen to the same music that other Latin American immigrants do-Caribbean rhythms, Tex Mex, Mexican-produced tunes, and music imported from their countries.
} 
Te aseguro y te llevo en el alma de mi guitarra. Te aseguro yo te quiero, como quiero a mi guitarra. Por eso quiero cantar, Por eso quiero reir, Por eso quiero llorar, Soy ilegal.

Por eso yo quiero ser, como el agua y como el viento, Para poderte querer, aunque sea por un momento. Por eso yo quiero ser, como el agua y como el viento, Para poderte querer,

Sin pensar en documentos.
I will secure you and take you

in the soul of my guitar.

I assure you that I love you, Like I love my guitar, That's why I want to sing, That's why I want to laugh, That's why I want to cry, I'm illegal. That's why I want to be, like the water, like the wind, so I can love you, even for just a moment. That's why I want to be, like the water, like the wind, so I can love you, without thinking about documents.

The songwriter Lilo González told me it was the contradiction that he feels Salvadorans have had in their hearts, of wanting to be back in their country but being unable to do so lest they cannot return, that has led him to write his songs. He explained: "Coming here was nice . . . to be able to sleep soundly knowing that nobody was going to knock on your door to disappear you in the middle of the night. . . . But at the same time, not having a driver's license, good documents, nothing here, this is what I mean by the contradiction in which Salvadorans have lived." When I asked him why and how he started to write songs and music, he responded: "It's pure nostalgia, depression that overwhelms you here, and it's something that stays with you for the rest of your life. Look at me, I'm a [U.S.] citizen now, but I'm marked for life. I still write and sing about that desperation that Salvadorans feel, to live longing for something that you carry in your soul and heart, but that you consciously have to put off seeing because you have to stay put, work, and send money." I asked him why he thought the Salvadorans' experience was any different from that of other Latin American immigrants, and he commented:

One thing that happened to many of us is that we weren't even able to say goodbye to family and friends because we had to leave at a moment's notice. . . Many are still stuck here without real documents to be able to go visit their family. If you look around at Christmastime and New Year's, you'll see how nostalgic Salvadorans get. They cry because these holidays are meant to be spent with family, but many can't go to be with them because they won't be able to come back. They have lived suspended lives for decades, with permits, temporary this and temporary that, and so they can't travel, as they wait and wait for a permanent adjustment. And they 


\section{American Journal of Sociology}

have to be here because they have to keep sending money, or else their families there don't eat.

Lilo's comment about the "suspended lives" he thinks Salvadorans have lived in the United States, and his references to "real papers" and the consequences of not having them, highlight the core of liminal legality I examine here. Sadly, even when these immigrants attain full legality and even citizenship (as in the case of Lilo) their early experiences in liminal legality continue to shape their views of their adopted country as well as those of their natal land.

The Salvadoran painter Karla Cecilia Rodas also captures the liminal state in which many Central Americans find themselves (Rodríguez 2005), as she poetically inscribes onto her canvas the endless legal entanglements in their lives. She devotes special attention to Central American women, who in Washington, D.C. (where Rodas is based), have been pioneers of Central American migration (Repak 1995). In Lamento Indígena II, one of Rodas's paintings, a mestiza woman is represented as having a foot in two worlds, one in an idealized tropical space with cornfields and volcanoes, and the other in a world of colorless and blurred buildings and the gray Capitol. Caught in midstride and looking back to the idealized space, this "border-crossing woman," Rodríguez (2005, p. 35) observes, captures the Salvadorans' ambivalent legal situation. But rather than a picture of nostalgia for a nation that cast her out, the painting represents the symbolic space of her immigration status (TPS), of living in a condition of permanent temporariness (Rodríguez 2005, p. 34). In this as well as in other paintings, Rodas represents the in-between narratives of Salvadoran women.

The same depictions are found in literature, as in two of the best-known Central American novels in the United States, where the issue of an uncertain legality is paramount. In the novel The Ordinary Seaman (Goldman 1997), Francisco Goldman, a journalist and writer of Guatemalan origin, depicts the lives of Central American refugees as an endless state of homelessness and uprooting, of people leaving harsh economic conditions and dislocation only to find the same in the United States due to their legal marginality. In Tattooed Soldier (Tobar 2000), the Guatemalan writer and journalist Héctor Tobar tells the story of two Guatemalan men, a revolutionary who fled his country to avoid execution and the soldier who murdered the revolutionary's wife and child. The two men live in Los Angeles where their legality is central. One of the men works for a courier company that specializes in sending goods and money to El Salvador and Guatemala, and the other is homeless and struggles even harder to survive. Both deal with the uncertain legality that makes their adjustment in the United States difficult. The book discusses conditions in 
war-torn Guatemala and the harsh reality of Los Angeles, while exposing U.S. military intervention in Central America and the exploitation of immigrants by U.S. capitalism. The story is infused with subtleties that may only have meaning for Guatemalans (and Salvadorans), such as the difficulty of travel for these immigrants, the persecution and terror in their country, and the ambiguity of their legal status and the consequences it has for their daily lives.

The forms of artistic expression examined here capture the uncertainty of the Central Americans' legal status and ambivalent feelings, the nostalgia that often accompanies their situation, and the strong influence of still-unresolved events back home and in the United States. The characters in the novels, films, paintings, and songs personify the violent history of displacement, a complex identity and status, and a harsh adaptation to the United States, conditions that are intimately linked to these immigrants' liminal legality and that continue to shape their views and aspirations. As such, artistic expressions of liminal legality will become part of the cultural repertoire to which future generations of Central Americans will look to as they shape their own identities.

\section{DISCUSSION AND CONCLUSION}

It is important to recognize that even though Central Americans have faced many challenges, they are not simply victims of political maneuvers beyond their control. To meet the challenges they have faced in the United States, Central Americans who arrived in the past two decades have organized to help fellow compatriots and to advocate for their rights. They have joined forces with Chicanos, Anglos, and others who share their political ideologies to lobby on behalf of their compatriots, to fight for improved working conditions, and to obtain permanent legal status. An important objective of these organizations has been to provide legal assistance, working both to help immigrants through the legalization process and to lobby for just immigration policies. It was largely due to the mounting pressure from immigrant-rights groups that the Justice Department eventually agreed to provide temporary protected status to Salvadorans and opportunities to resubmit asylum applications both to them and to Guatemalans. As Central Americans have settled and established their families, the objectives of these solidary organizations have switched to issues associated with a more permanent settlement. They now advocate for longer-term projects, rights, and approaches that reflect the increasing settlement of this group as well as the end of the armed conflicts in Central America. An important fact to note is that Central American immigrants work with the law as a means to obtain justice. Coutin (2000b) 
American Journal of Sociology

observes that in their efforts to define themselves as legal, these immigrants and their advocates contest and sometimes even redefine and reinterpret the law so as to demonstrate that their claims to legal status are valid.

Central Americans also have organized to advocate for their rights as workers and as members of the communities in which they live. They have lobbied city councils to legalize street vending, have organized janitors to fight for better working conditions and pay, have worked tirelessly to open and maintain day laborer centers, and have worked arduously to make their neighborhoods safer. Hamilton and Chinchilla (2001) detail the history of the organization Justice for Janitors in Los Angeles, in which Central Americans took a leadership role. Thus, even though their claims to permanent legal status have not been heard and many still live in the "shadow of the law," many of these immigrants have responded by organizing, working with the law, and contesting the conditions in which they live.

The case of Salvadorans and Guatemalans attests to the enduring power of the nation-state in defining who belongs, who is excluded, and the formal basis for the rights and responsibilities of the individual in the state, as through its policies it channels individuals to different paths or assimilation. This case demonstrates the impact immigration law has on the lives of immigrants, and how in turn they adjust and attempt to conform to the law, possibly redefining structures in the process, including their relationship to the polity and the institution of citizenship. This case also demonstrates that what states do through their immigration policies still matter a great deal (Weil cited in Miller 2001). It exposes novel ways of immigrant participation in the national community-reconfigured family forms, new and varied perceptions of religious institutions, and new voice and views in the creation of art. This examination brings into focus the quotidian effects of the multiple categories created by the law, as the experiences of Central Americans blur the black-and-white distinction between legal and undocumented statuses and allow us to examine what living in this gray area may be like for immigrants. Although the immigrants in situations of suspended or liminal legality live in the same communities and neighborhoods as other immigrants, and their children attend the same schools, a close-up look at the social and cultural spheres of their lives reveals the mighty impact of the law.

Extended periods of liminal legality may eventually change the very notion of citizenship, as these fragmented, bumpy relations to the state might transform the institution of citizenship through migration. Immigration policies shape immigrants' incorporation, and thus debates about the appropriateness of classical frameworks of assimilation for the study of contemporary immigrants (see Alba and Nee 2003) should seriously 
consider policies and immigrants' legality. In the face of increasingly restrictive policies that "irregularize" people (see Calavita 1998) and keep immigrants on the margins of society for lengthy periods of time, one might wonder what, precisely, the effects will be on assimilation and on citizenship itself (legal and other forms). Also, scholars of Latino politics have argued that lack of citizenship is the single most important obstacle for Latino political empowerment (Pantoja 2005). Thus, obstructed paths to attain legal citizenship might have broader and deeper effects on other forms of citizenship. The case I present reminds us that in the face of much movement across borders, the state continues to hold great power, as through its laws it delimits, constrains, and affords rights, privileges, duties, and responsibilities. As Peter Andreas (2000) observes, loss-ofcontrol arguments serve as powerful narratives that obscure the ways in which government practices themselves create the very conditions that generate calls for and justify increased state authority.

\section{REFERENCES}

Alba, Richard, and Victor Nee. 2003. Remaking the American Mainstream: Assimilation and Contemporary Immigration. Cambridge, Mass.: Harvard University Press.

Aleinikoff, T. Alexander. 2001. "Policing Boundaries: Migration, Citizenship, and the State. Pp. 267-291 in E Pluribus Unum? Contemporary and Historical Perspectives on Immigrant Political Incorporation, edited by Gary Gerstle and John Mollenkopf. New York: Russell Sage Foundation.

Andreas, Peter. 2000. Border Games: Policing the U.S.-Mexico Divide. Ithaca, N.Y.: Cornell University Press.

Bailey, Adrian J., Richard A. Wright, Alison Mountz, and Ines M. Miyares. 2002. "(Re)producing Salvadoran Transnational Geographies." Annals of the Association of American Geographers 92 (1): 125-44.

Bauböck, Rainer. 1994. Transnational Citizenship: Membership and Rights in International Migration. Aldershot: Edward Elgar.

Bean, Frank, Edward E. Telles, and B. Lindsay Lowell. 1987. "Undocumented Migration to the United States: Perceptions and Evidence." Population and Development Review 13 (4): 671-90.

Bernstein, Nina. 2004. "Concern Grows for Families Broken Up by Deportation." Arizona Republic, A10, November 24.

Bloemraad, Irene. 2004. "Who Claims Dual Citizenship? The Limits of Postnationalism, the Possibilities of Transnationalism, and the Persistence of Traditional Citizenship." Internationa Migration Review 38 (2): 389-426

Briody, Elizabeth K. 1987. "Patterns of Household Immigration into South Texas." International Migration Review 21:27-47

Bosniak, Linda. 1991. "Human Rights, State Sovereignty and the Protection of Undocumented Migrants under the International Migrant Workers Convention." International Migration Review 25 (4): 737-70

—. 1998. "The Citizenship of Aliens." Social Text 16 (3): 29-35.

. 2000. "Citizenship Denationalized." Indiana Journal of Global Legal Studies 7:447-92

Bozorgmehr, Mehdi. 1997. "Internal Ethnicity: Iranians in Los Angeles." Sociological Perspectives 40 (3): 387-408. 


\section{American Journal of Sociology}

Cadge, Wendy, and Elaine Howard Ecklund. In press. "Religious Service Attendance among Immigrants: Evidence from the New Immigrant Survey-Pilot.” American Behavioral Scientist, vol. 49.

Calavita, Kitty. 1998. "Immigration, Law and Marginalization in a Global Economy: Notes from Spain." Law and Societv Review 32 (3): 529-66.

Canadian Council for Refugees. 2004. More than a Nightmare: Delays in Refugee Family Reunification. Report issued November 11. http://www.web.ca/ ccr/ nightmare.pdf.

Castells, Manuel. 1989. The Informational City: Information Technology, Economic Restructuring, and the Urban-Regional Process. Oxford: Blackwell.

Chavez, Leo R. 1991. "Outside the Imagined Community: Undocumented Settlers and Experiences of Incorporation." American Ethnologist 18 (2): 257-78.

Chiswick, Barry P. 1984. "Illegal Aliens in the United States Labor Market: Analysis of Occupational Attainment and Earnings." International Migration Review 18 (3): 714-32.

Coutin, Susan. 2000a. "Denationalization, Inclusion, and Exclusion: Negotiating the Boundaries of Belonging." Indiana Journal of Global Legal Studies 7:585-91.

- 2000b. Legalizing Moves: Salvadoran Immigrants' Struggle for U.S. Residency. Ann Arbor: University of Michigan Press.

De Genova, Nicholas P. 2002. "Migrant 'Illegality' and Deportability in Everyday Life." Annual Review of Anthropology 31:419-47.

Dow, Mark. 2004. American Gulag: Inside U.S. Immigration Prisons. Berkeley and Los Angeles: University of California Press.

Epicentroamerica. 2001-2. Bienvenidos a Epicentroamerica: Selections. Long Beach, Calif.: Guacamaya Publishing.

Freeman, Gary. 2004. "Immigrant Incorporation in Western Democracies." International Migration Review 38 (3): 945-69.

Gamburd, Michele Ruth. 2000. The Kitchen Spoon's Handle: Transnationalism and Sri Lanka's Migrant Households. Ithaca, N.Y.: Cornell University Press.

Goldman, Francisco. 1997. The Ordinary Seaman. New York: Atlantic Monthly Press. Grasmuck, Sherri. 1984. "Immigration, Ethnic Stratification, and Native Working Class Discipline: Comparisons of Documented and Undocumented Dominicans." International Migration Review 18 (3): 692-713.

Guiraudon, Virginie, and Christian Joppke. 2001. "Controlling a New Migration World." Pp. 1-27 in Controlling a New Migration World, edited by Virginie Guiraudon and Christian Joppke. London: Routledge.

Guttmacher, Sally. 1984. "Immigrant Workers: Health, Law, and Public Policy." Journal of Health Politics. Policv and the Law 9 (3): 503-14.

Hamilton, Nora, and Norma Stoltz Chinchilla. 2001. Seeking Community in a Global City: Guatemalans and Salvadorans in Los Angeles. Philadelphia: Temple University Press.

Hammar, Thomas. 1990. Democracy and the Nation State: Aliens, Denizens and Citizens in a World of International Migration. Brookfield, Vt.: Ashgate Publishing.

Hernández-Linares, Leticia. 2002. Razor Edges of My Tongue. San Diego, Calif.: Calaca Press.

Heyman, Josiah M. 1998. "State Effects on Labor Exploitation: The INS and Undocumented Immigrants at the Mexico-United States Border." Critique of Anthropology 18 (2): 157-80.

Hirsch, Jennifer S. 2003. A Courtship after Marriage: Sexuality and Love in Mexican Transnational Families. Berkeley and Los Angeles: University of California Press.

Hondagneu-Sotelo, Pierrette, and Ernestine Avila. 1997. "I'm Here, but I'm There: The Meanings of Latina Transnational Motherhood." Gender and Societv 11:548-71.

Howley, Chris. 2005. "Young Migrants Crossing All Alone." Arizona Republic, p. A1. January 19. 


\section{Liminal Legality}

INS (Immigration and Naturalization Service). 1997. "INS Releases Updated Estimates of U.S. Illegal Population." News release, February 7. U.S. Department of Justice, Washington, D.C.

Jacobson, David. 1996. Rights across Borders: Immigration and the Decline of Citizenship. Baltimore: Johns Hopkins University Press.

Jones-Correa, Michael. 1998. Between Two Nations: The Political Predicament of Latinos in New York. Ithaca, N.Y.: Cornell University Press.

Kil, Sang, and Cecilia Menjívar. In press. "The Criminalization of Immigrants and Militarization of the Border: Recent Lessons from Arizona." In Immigration and Crime: Ethnicity, Race and Violence. Edited by Ramiro Martinzez, Jr., and Abel Valenzuela, Jr. New York: New York University Press.

Landolt, Patricia, Lilian Autler, and Sonia Baires. 1999. "From Hermano Lejano to Hermano Mayor: The Dialectics of Salvadoran Transnationalism." Ethnic and Racial Studies 22 (2): 290-315.

Leslie, Leigh A. 1993. "Families Fleeing War: The Case of Central Americans." Marriage and Familv Review 19:193-205.

Lopez, David E., Eric Popkin, and Edward Telles. 1996. "Central Americans: At the Bottom, Struggling to Get Ahead.” Pp. 279-304 in Ethnic Los Angeles, edited by R. Waldinger and M. Bozorgmehr. New York: Russell Sage Foundation.

Mahler, Sarah J. 1995. Salvadorans in Suburbia: Symbiosis and Conflict. Boston: Allyn \& Bacon.

Malkki, Liisa H. 1995. Purity and Exile: Violence, Memory, and National Cosmology among Hutu Refugees in Tanzania. Chicago: University of Chicago Press.

Martiniello, Marco. 1997. "Citizenship, Ethnicity, and Multiculturalism: Post-national Membership between Utopia and Reality." Ethnic and Racial Studies 20 (3): 635-41.

Massey, Douglas S., Jorge Durand, and Nolan J. Malone. 2002. Beyond Smoke and Mirrors: Mexican Immigration in an Era of Economic Integration. New York: Russell Sage Foundation.

Menjívar, Cecilia. 1997. "Immigrant Kinship Networks and the Impact of the Receiving Context: Salvadorans in San Francisco in the early 1990s." Social Problems 44 (1): 104-23.

1999a. "The Intersection of Work and Gender: Central American Immigrant Women and Employment in California." American Behavioral Scientist 42 (4): 595-621.

. 1999b. "Religious Institutions and Transnationalism: A Case Study of Catholic and Evangelical Salvadoran Immigrants." International Journal of Politics, Culture and Societv 12:589-612.

. 2000. Fragmented Ties: Salvadoran Immigrant Networks in America. Berkeley and Los Angeles: University of California Press.

. 2001. "Latino Immigrants and Their Perceptions of Religious Institutions: Cubans, Salvadorans, and Guatemalans in Phoenix, AZ." Migraciones Internacionales 1 (1): 65-88.

. 2002a. "Living in Two Worlds? Guatemalan-Origin Children in the United States and Emerging Transnationalism." Journal of Ethnic and Migration Studies 28:531-52.

. 2002b. "The Ties that Heal: Guatemalan Immigrant Women's Networks and Medical Treatment." International Migration Review 36 (2): 437-66.

. 2003. "Religion and Immigration in Comparative Perspective: Salvadorans in Catholic and Evangelical Communities in San Francisco, Phoenix, and Washington, D.C." Sociology of Religion 64:21-45.

Miller, Mark. 2001. "The Sanctioning of Unauthorized Migration and Alien Employment." Pp. 318-36 in Global Human Smuggling: Comparative Perspectives, edited by David Kyle and Rey Koslowski. Baltimore: Johns Hopkins University Press. 


\section{American Journal of Sociology}

Miller Matthei, Linda, and David A. Smith. 1998. "Belizean 'Boyz 'n the 'Hood'? Garifuna Labor Migration and Transnational Identity." Pp. 270-90 in Transnationalism from Below. Edited by M. P. Smith and L. E. Guarnizo. New Brunswick, N.J.: Transaction Publishers.

Morales, Marlon I. 2001. A Tease: Selections from the Forthcoming Collection: Turning Tricks: Poems. Los Angeles, Calif.: Izote Press.

Mountz, Alison, Richard Wright, Ines Miyares, and Adrian J. Bailey. 2002. "Lives in Limbo: Temporary Protected Status and Immigrant Identities." Global Networks 2 (4): $335-56$.

National Asylum Study Project. 1992. "An Interim Assessment of the Asylum Process of the Immigration and Naturalization Service." Washington, D.C., and Cambridge, Mass.: Harvard University, Harvard Law School, Immigration and Refugee Program.

Pantoja, Adrian. 2005. "Political Orientations, Gender and Naturalization among Latino Immigrants." Paper presented at the annual meeting of the Western Political Science Association, Oakland, Calif. March.

Phillips, Julie A., and Douglas S. Massey. 1999. "The New Labor Market: Immigrants and Wages after IRCA.” Demography 36 (2): 233-46.

Popkin, Eric. 1999. "Guatemalan Mayan Migration to Los Angeles: Constructing Transnational Linkages in the Context of the Settlement Process." Ethnic and Racial Studies 22 (2): 267-89.

Portes, Alejandro, and Rubén G. Rumbaut. 1996. Immigrant America: A Portrait. Berkeley and Los Angeles: University of California Press.

Portes, Alejandro, and Min Zhou. 1993. "The New Second Generation: Segmented Assimilation and Its Variants." Annals of the American Academy of Political and Social Science 530:74-96.

Reitz, Jeffrey G. 1998. Warmth of the Welcome: The Social Causes of Economic Success for Immigrants in Different Nations and Cities. Boulder, Colo.: Westview Press.

Repak, Terry A. 1995. Waiting on Washington: Central American Workers in the Nation's Capital. Philadelphia: Temple University Press.

Rodríguez, Ana Patricia. 2001. "Refugees of the South: Central Americans in the U.S. Latino Imagery." American Literature 73 (2): 387-412.

- 2002a. "Fronteras Centroamericanas, Centroamericanos Fronterizos." A Quien Corresponda: Literatura Virtual. http://www.angelfire.com/va3/literatura/ ANAPATRICIA.htm. Viewed 23 February.

.2002b. "Projections of Homeland: Remembering the Civil War in El Salvador." Paper presented at the conference "The Interpretation and Representation of Latino Cultures: Research and Museums Conference Documentation, Smithsonian Center for Latino Initiatives." Smithsonian Institution, May 14.

—. 2005. "Departamento 15': Cultural Narratives of Salvadoran Transnational Migration." Latino Studies 3 (1): 19-41.

Rodriguez, Nestor P. 2003. "What's Old and What's New: Guatemalan Immigrants in Houston." Paper presented at the Latin American Studies Association Meetings, Dallas, March.

Rodriguez, Nestor P., and Jacqueline Hagan. 1999. "Central Americans." Pp. 278-96 in The Minority Report: An Introduction to Racial, Ethnic, and Gender Relations, 3d ed. Edited by A. G. Dworkin and R. J. Dworkin. Dallas: Harcourt Brace Jovanovich.

2004. "Fractured Families and Communities: Effects of Immigration Reform in Texas, Mexico, and El Salvador." Latino Studies 2 (3): 328-351.

Rubenstein, Kim, and Daniel Adler. 2000. "International Citizenship: The Future of Nationality in a Globalized World." Indiana Journal of Global Legal Studies 7: 519-40.

Rubio-Marín, Ruth. 2000. Immigration as a Democratic Challenge: Citizenship and 


\section{Liminal Legality}

Inclusion in Germany and the United States. Cambridge: Cambridge University Press.

Salcido, Olivia, and Madelaine Adelman. 2004. "He Has Me Tied with the Blessed and Damned Papers: Undocumented-Immigrant Battered Women in Phoenix, Arizona." Human Organization 63 (2): 162-72.

Sassen, Saskia. 2000. "The Need to Distinguish Denationalized and Postnational." Indiana Journal of Global Legal Studies 7: 575-81.

—. 2002. "Towards Post-National and Denationalized Citizenship." Pp. 277-91 in Handbook of Citizenship Studies, edited by Engin F. Isin and Bryan S. Turner. London: Sage.

. 2003. "The Participation of States and Citizens in Global Governance." Indiana Journal of Global Legal Studies 10:5-28.

Simon, Rita J., and Margo DeLey. 1984. "The Work Experience of Undocumented Mexican Women Migrants in Los Angeles." International Migration Review 18 (4): 1212-29.

Soysal, Yasemin Nuhoglu. 1994. Limits of Citizenship: Migrants and Postnational Membership in Europe. Chicago: University of Chicago Press

. 2000. "Citizenship and Identity: Living in Diasporas in Post-War Europe?" Ethnic and Racial Studies 23 (1): 1-15.

Tobar, Héctor. 2000. Tattooed Soldier. New York: Penguin.

Turner, Victor. 1967. The Forest of Symbols: Aspects of Ndembu Ritual. Ithaca, N.Y.: Cornell University Press.

Uriarte, Miren, Phil Granberry, Megan Halloran, Susan Kelly, Rob Kramer, and Sandra Winkler. 2003. "Salvadorans, Guatemalans, Hondurans and Colombians: A Scan of Needs of Recent Latin American Immigrants to the Boston Area." Manuscript. University of Massachusetts, Boston, Program in Public Policy, John W. McCormack School of Policy Studies.

Warner, R. Stephen. 1998. "Immigration and Religious Communities in the United States. Pp. 3-34, in Gatherings in Diaspora: Religious Communities and the New Immigration, edited by R. S. Warner and J. G. Wittner. Philadelphia: Temple University Press.

Wright, Jeff. 2005. "Judge Extends Immigration Case for Boy." Register-Guard, D1. November 30.

Zolberg, Arisitide R. 2000. "The Dawn of Cosmopolitan Denizenhip.” Indiana Journal of Global Legal Studies 7:511-16.

Zolberg, Aristide, Astri Suhrke, and Sergio Aguayo. 1989. Escape from Violence: Conflict and the Refugee Crisis in the Developing World. New York: Oxford University Press. 